\title{
UNIDADE NA DIVERSIDADE: OS FUNDAMENTOS DO DIREITO COSMOPOLITA E SUA FUNÇÃO NO ESTABELECIMENTO DE UMA MOEDA MUNDIAL
}

\author{
Fernando dos Santos Lopes
}

UNITY IN DIVERSITY: THE PRINCIPLES OF COSMOPOLITAN LAW AND ITS ROLE IN THE ESTABLISHMENT OF A WORLD CURRENCY

\section{RESUMO}

ESTE ARTIGO OBJETIVA VERIFICAR SE É POSSÍVEL E COMO É POSSÍVEL UTILIZAR O DIREITO COSMOPOLITA PARA RECONSTRUIR A ATUAL ORDEM MUNDIAL SEGUNDO PRINCÍPIOS DE JUSTIÇA, DE MODO A ALCANÇAR A PAZ PERPÉTUA E ELIMINAR A POBREZA. SERÃo EXPOSTOS OS FUNDAMENTOS DO DIREITO COSMOPOLITA, CONTRASTANDO-OS COM AS RELAÇÕES DE PODER VIGENTES NO ÂMBITO INTERNACIONAL QUE SÃO CARACTERIZADAS COMO DE INTERDEPENDÊNCIA ASSIMÉTRICA. PARTINDO-SE DA PREMISSA DE QUE AS SOCIEDADES CONTEMPORÂNEAS PODEM SER COMPREENDIDAS COMO SISTEMAS QUE OSCILAM ENTRE A COOPERAÇÃO E O CONFLITO, SERÃO ANALISADAS AS ESTRUTURAS INSTITUCIONAIS SUBJACENTES A ESSA TENSÃO SOCIAL, COM DESTAQUE PARA O FUNCIONAMENTO DO SISTEMA MONETÁRIO INTERNACIONAL. APÓS A IDENTIFICAÇÃO DOS FATORES INSTITUCIONAIS CAUSADORES DO CONFLITO E DA POBREZA, ANALISAREMOS A PROPOSTA OFERECIDA POR KEYNES, EM BRETTON WOODS, DE CRIACCÃO DE UMA MOEDA MUNDIAL DE RESERVA. ISSO SERÁ FEITO COM O INTUITO DE CONSTATAR SE ESSA PROPOSTA SE ADEQUA AOS FUNDAMENTOS DO DIREITO COSMOPOLITA NO SENTIDO DE SER UM MEIO DE ELIMINAR A INJUSTIÇA, RETIRANDO, POR CONSEGUINTE, O PRINCIPAL ÓBICE PARA O ATINGIMENTO DA PAZ.

PALAVRAS-CHAVE

Direito Cosmopolita; Moeda mundial; Princípios de Justiça.

\begin{abstract}
THE OBJECTIVE OF THIS WORK IS TO VERIFY WHETHER IT IS POSSIBLE AND HOW YOU CAN USE THE COSMOPOLITAN LAW TO REBUILD THE CURRENT WORLD ORDER ACCORDING TO PRINCIPLES OF JUSTICE, A WAY TO ACHIEVE EVERLASTING PEACE AND ELIMINATE POVERTY. IT WILL BE EXPOSED TO THE FUNDAMENTALS OF COSMOPOLITAN LAW, CONTRASTING THEM WITH THE POWER RELATIONS PREVAILING IN THE INTERNATIONAL ARENA THAT ARE CHARACTERIZED AS ASYMMETRICAL INTERDEPENDENCE. BASED ON THE PREMISE THAT CONTEMPORARY SOCIETIES CAN BE UNDERSTOOD AS SYSTEMS THAT OSCILLATE BETWEEN COOPERATION AND CONFLICT, WILL BE ANALYZING THE INSTITUTIONAL STRUCTURES THAT UNDERLIE SOCIAL TENSION, ESPECIALLY THE FUNCTIONING OF THE INTERNATIONAL MONETARY SYSTEM. AFTER IDENTIFYING THE INSTITUTIONAL FACTORS THAT CAUSE CONFLICT AND POVERTY WILL BE ANALYZED THE PROPOSAL OFFERED BY KEYNES AT BRETTON WOODS TO CREATE A WORLD RESERVE CURRENCY, WHICH WILL BE DONE IN ORDER TO DETERMINE WHETHER THIS PROPOSAL FITS TO THE FUNDAMENTALS OF COSMOPOLITAN IN THE SENSE OF BEING A MEANS OF ELIMINATING INJUSTICE REMOVING THEREFORE THE MAIN OBSTACLE TO THE ACHIEVEMENT OF PEACE.

\section{KEYWORDS}

Cosmopolitan Law; Global CuRrency; Principles of Justice.

\section{INTRODUÇÃO}

Após o impacto gerado pelas ideias de Rawls referentes à construção de instituições sociais segundo princípios de justiça, ${ }^{1}$ alguns de seus mais proeminentes discípulos iniciaram uma discussão acerca da viabilidade de não restringir a aplicação desses 
princípios ao âmbito interno de determinadas sociedades. Ou seja, pretendeu-se expandir a aplicação dos princípios de justiça para o contexto das relações internacionais.

Ocorre, contudo, que os princípios de justiça propostos por Rawls a partir do artifício epistemológico da posição original foram desenvolvidos para promover a justiça num contexto de cooperação, o que implicaria a necessidade de se verificar, num primeiro momento, qual a espécie de relação que existe atualmente entre os Estados nacionais.

Dependendo do que fosse constatado, seria possível iniciar uma discussão acerca da viabilidade de se aplicar a teoria da justiça desenvolvida por Rawls em âmbito internacional, ou mesmo alguma outra concepção de justiça, tal como a cosmopolita, que será exposta neste trabalho.

Ao contrário do filósofo político, o teórico do Direito não pode se limitar à formulação de princípios de justiça e, diferentemente do sociólogo, não pode se limitar a descrever o funcionamento das instituições sociais. Além de conhecer os aspectos filosóficos e sociológicos relacionados à questão da justiça, ele deve descrever as medidas que deveriam ser consubstanciadas em leis com o intuito de tornar a justiça entre os povos uma situação real, com vistas a se obter um estado de paz perpétua.

Com efeito, a paz mundial que se busca atingir por meio do Direito Cosmopolita é uma paz perpétua derivada da justiça, e não uma paz constantemente ameaçada por guerras e revoluções. ${ }^{2}$

Tendo em vista esse contexto, após uma interpretação dos princípios de justiça cosmopolita contidos na Declaração de Princípios sobre a Tolerância, ${ }^{3}$ na declaração sobre o direito ao desenvolvimento ${ }^{4}$ e no Pacto Internacional de Direitos Econômicos e Sociais ${ }^{5}$ faremos uma análise das relações de poder no âmbito internacional, com especial destaque para as relações monetárias, de modo a investigar se a implantação de uma moeda mundial seria uma medida idônea a tornar as relações internacionais adequadas aos princípios de justiça cosmopolita, o que representaria um passo importante no sentido de se construir uma nova ordem mundial fundada na paz perpétua derivada da justiça.

\section{O PRINCÍPIO DA TOLERÂNCIA}

Da Declaração de Princípios sobre a Tolerância é possível extrair que o princípio da tolerância não exige, por exemplo, que muçulmanos passem a aceitar como corretos os ensinamentos judaicos, ou vice-versa, mas exige que todas as religiões professem a fé no direito de todos serem livres para seguir a religião que quiserem. Ou seja, o limite jurídico que deve ser imposto às religiões é o imperativo do respeito à liberdade religiosa do próximo: seja livre para professar qualquer religião, conquanto permita que o outro também seja livre. 
Prima facie, pode parecer contraditório afirmar que a liberdade surge como consequência da imposição de um dever. No entanto, tal contradição é apenas aparente, uma vez que esse dever consiste numa forma especial de um dever moral: o dever de ser livre.

O conceito de tolerância se opõe ao conceito de imposição. O indivíduo tolerante se abstém de impor seus pensamentos a outrem, pois, embora discordante no que se refere às concepções do próximo, não procura impor por meio da força, seja esta legal ou não, a aceitação de seu próprio pensamento.

Trata-se por certo de um princípio de caráter ético por excelência, uma vez que voltado a reger processos intersubjetivos. Numa sociedade tolerante, um cidadão judeu deve respeitar os ensinamentos de um cidadão muçulmano, e vice-versa.

Isso não significa que os dois devam pensar da mesma forma, pois se assim o fosse não precisaria haver tolerância. Com efeito, a função do princípio da tolerância é justamente proporcionar paz a um ambiente de opiniões divergentes. Ora, se judeus e muçulmanos pensassem da mesma forma, não haveria o que ser tolerado.

O princípio da tolerância implica a existência de uma simetria no respeito às diferenças, não significando, por certo, a eliminação dessas diferenças. Tudo aquilo tendente a impor um único posicionamento para acabar com as diferenças é incompatível com a tolerância e, por conseguinte, com a democracia que tem sua existência vinculada a um regime de discussão, e não de imposição.

Além disso, um ponto que deve ser destacado é que a tolerância não é voltada única e exclusivamente a reger as relações entre os Estados, sendo, acima de tudo, um direito humano absoluto. 6

Como direito humano absoluto, vincula tanto as relações entre os Estados quanto entre estes e os membros da família humana, pouco importando as questões relativas à nacionalidade desses membros. Em outras palavras, um Estado não pode invocar o dever de tolerância de outro povo se não pratica a tolerância no interior de suas fronteiras, pois isso corresponderia a exigir que os Estados soberanos tolerassem a intolerância, o que é uma contraditio in terminis.

Sendo assim, um Estado muçulmano deve permitir que seus cidadãos se convertam ao cristianismo, e um Estado cristão deve permitir que seus cidadãos se convertam ao islamismo. O mesmo se aplica para questões relativas à orientação sexual, casamentos, etc.

Tal como se pode ver, o respeito ao princípio da tolerância é uma condição para a existência de uma sociedade verdadeiramente livre. Por outro lado, tolerância não é sinônimo de relativismo, mas também não se confunde com o que os filósofos contemporâneos normalmente associam ao conceito de vida boa.

Ao mesmo tempo em que o princípio da tolerância traz consigo uma determinada visão de mundo substancial, consistente na crença de que todos têm o direito de ter a visão de mundo que quiserem, ele não indica qual é a melhor visão de mundo que todos têm o direito de ter. 
Sendo assim, se as mulheres de um povo se sentem felizes em se mutilar, ou se sentem felizes em colocar argolas no pescoço, assim como ocorre na Tailândia, não cabe aos países que não possuem esses costumes procurar criar mecanismos a fim de proibir tais traços de manifestação cultural.

Por outro lado, a comunidade internacional tem o dever de impedir que mulheres, sobretudo se forem crianças, sejam forçadas a realizar esse comportamento, pois a opressão e a imposição são manifestamente incompatíveis com o princípio da tolerância .

Analogamente, não se pode tolerar que as pessoas de um país sejam privadas da justa distribuição dos bens produzidos por causa da corrupção de seus governos, ou por qualquer outra circunstância incompatível com os princípios de justiça. O mesmo se aplica ao âmbito internacional, pois não se pode tolerar que as instituições internacionais sejam configuradas de modo a favorecer poucos em detrimento de muitos.

Corroborando essas assertivas está a Declaração de Princípios sobre a Tolerância (1995, art. $\left.1^{\circ}, 1.4\right)$, que de modo taxativo afirma: "ser tolerante não significa ser tolerante com a injustiça social”.

O princípio da tolerância, portanto, pode ser vislumbrado como um dos principais princípios a promover uma nova ordem mundial fundada na unidade em meio à diversidade.

\section{I O PRINCÍPIO DO PROVEITO MúTUO}

Quando se fala acerca de princípios de conteúdo moral que posteriormente foram positivados como princípios jurídicos, como os de direitos humanos, deve-se ter em conta que esses princípios não são positivados consoante um único significado moral substancial, uma vez que procuram consubstanciar num todo coerente a pluralidade “cosmovisiológica” presente no âmbito interno ou internacional, conforme o caso.

Por outro lado, a condição de possibilidade dessa pluralidade "cosmovisiológica" procedimental é uma concepção substancial, ou seja, o respeito ao princípio da tolerância. O princípio da tolerância está implícito no próprio processo de positivação, que é caracterizado pela discussão entre povos de culturas diferentes, sendo que o objeto de discussão consiste na busca por princípios de justiça adequados a impedir que a humanidade seja novamente vitimada pelos flagelos da guerra.

Como expressão desse processo regido pela tolerância, surge o princípio do proveito mútuo, que se apresenta como uma síntese coerente da visão deontológica e da visão consequencialista, englobando as diretrizes fundamentais que orientaram a elaboração do pacto internacional sobre direitos econômicos, sociais e culturais.

Ao mesmo tempo em que o pacto internacional sobre direitos econômicos, sociais e culturais assegura que "todos os povos podem dispor livremente de suas riquezas e de seus recursos naturais" (1992, art. $1^{\circ}$, 2) ele determina a cooperação econômica entre os Estados, e que o resultado desse processo de liberdade econômica 
aliado à cooperação esteja vinculado ao proveito de todos os Estados participantes do processo.

O referido pacto também possui um núcleo moral rígido, uma vez que determina que "em caso algum, poderá um povo ser privado de seus meios de subsistência." (Pacto, 1992, art. $1^{\circ}, 2$ ). É razoavelmente fácil compreender como o princípio do proveito mútuo está fundado na ideia de unidade na diversidade. Por meio da livre disponibilidade de recursos, cada Estado poderá desenvolver sua economia consoante suas particularidades e necessidades.

Já a cooperação econômica internacional pode ser vista como um processo de divisão de trabalho de caráter global que tem como meta otimizar a produção, para obter uma riqueza tão diversificada quanto sejam as necessidades dos diferentes membros da família humana.

Esse resultado de bem-estar mundial só poderá ser sustentável se implementado em benefício de todos, uma vez que, do contrário, ter-se-á uma situação de injustiça que inexoravelmente levará a um estado de guerra, consoante uma das premissas fundamentais deste trabalho, ou seja, a de que a guerra é consequência da injustiça ou da intolerância.

Para que a paz perpétua seja alcançada, é preciso que as instituições internacionais sejam justas e tolerantes, ou seja, que entre outros fatores não coloquem um Estado em posição superior a outro, não podendo existir portanto qualquer diferença entre os Estados, mas apenas complementaridade.

A melhor metáfora para compreender a teleologia do princípio da complementaridade é pensar no funcionamento do corpo humano. Cada parte do corpo difere de outra sem que isso possa ser apontado como um problema. Ao contrário, a diversidade de funções desempenhadas por diferentes órgãos é fundamental para o bem-estar do todo.

Analogamente, cada Estado precisa ser considerado importante, caso se queira realmente atingir o objetivo de se formar uma nova ordem mundial de caráter cosmopolita. Diferenças econômicas e culturais devem ser mantidas na medida em que contribuam para criar uma unidade em meio à diversidade, na qual o bem-estar de um corresponda ao mesmo tempo ao bem-estar do outro.

Atingida essa unidade na diversidade que se apresenta como condição para a realização da justiça, e consequentemente para a obtenção da paz, a seguinte frase de Habermas passa a fazer todo sentido: "Uma pessoa só pode ser livre se todas as demais o forem igualmente” (2004, p. 13). De forma análoga: um Estado só pode ser livre se todos os demais o forem igualmente.

Nesse sentido, cabe aos Estados optar pela construção de uma nova ordem mundial segundo o princípio do proveito mútuo.

\section{I.2 O PRINCÍPIO DA AUTODETERMINAÇÃO COMO COROLÁRIO DO DEVER DE TOLERÂNCIA}

O princípio da autodeterminação pode ser considerado a manifestação do princípio 
da liberdade na esfera internacional, possuindo uma dimensão interna e outra externa. No que se refere à dimensão externa, todos os povos devem possuir liberdade para se desenvolverem conforme suas peculiares características econômicas, religiosas e culturais, desde que fundados no alicerce da justiça e respeitosos do direito dos outros Estados de possuírem a mesma liberdade. Trata-se portanto de um direito à liberdade que apenas surge quando satisfeito um dever de tolerância. O conteúdo daquilo que se considera justo, por sua vez, consubstancia princípios morais hoje positivados no âmbito internacional sob a forma jurídica.

Para que seja possível a autodeterminação no âmbito externo, contudo, é fundamental ainda o respeito ao princípio da tolerância no âmbito interno, o que constitui a segunda dimensão do princípio da autodeterminação. Para que um Estado possa exigir o respeito dos outros países por suas manifestações culturais que num âmbito liberal poderiam ser consideradas violações dos direitos humanos, por exemplo, ele deve respeitar a vontade divergente de seus cidadãos em relação às referidas práticas culturais, sociais, econômicas ou religiosas.

Um Estado que defende como parte de sua cultura a mutilação genital de mulheres, por exemplo, não poderia exigir que outros Estados respeitassem essa forma de manifestação cultural se as mulheres não são mutiladas por livre e espontânea vontade, mas obrigadas por meios físicos, ou mesmo mediante coação moral, social ou institucional.

Um aspecto interessante do princípio da autodeterminação, no que se refere à sua dimensão interna, é que a violação dessa dimensão por parte de um Estado pode dar origem a um dever a ser realizado por parte dos outros Estados. É que a imposição por parte de um Estado de uma cultura ou forma de pensamento a todos os seus cidadãos, sem que haja respeito às vontades divergentes, e consequentemente ao dever de tolerância, pode gerar conflitos e perseguições que não raro implicam a existência de refugiados.

Cabe aos Estados livres assegurar refúgio aos perseguidos, podendo-se citar os refugiados da Líbia como exemplo na contemporaneidade. Tal como se pode inferir, o princípio moral que sustenta o direito à autodeterminação consiste na premissa de que ninguém pode exigir a liberdade se não permite a liberdade de seu próximo.

\section{I.3 O PRINCÍPIO DA COOPERAÇÃO}

O princípio da cooperação pode ser entendido como manifestação do princípio da solidariedade no âmbito internacional. É preciso distinguir, contudo, solidariedade de assistencialismo, ou mesmo do que Rawls (1999, p. 106ss) chama de dever de assistência. O conceito de solidariedade traz consigo a crença de que cada pessoa possui um valor único e inestimável, estando a plena felicidade de um indivíduo condicionada à plena felicidade de todos. Assim, os atos de solidariedade representam a crença de que ao ajudar o próximo o indivíduo ajuda a si mesmo. 
A solidariedade, portanto, não representa uma relação superior-inferior, mas uma relação todo-parte, uma vez que os sujeitos passam a ser vistos como membros de um único corpo social que retira o significado de sua unidade da diversidade de seus membros. Esses membros por sua vez relacionam-se de modo complementar, sendo o termo complementaridade o que aparentemente melhor expressa o significado da igualdade no plano internacional.

Trata-se, portanto, de um princípio que no plano internacional tem a função de direcionar a política de cada Estado para o bem de todos, o que permitirá que o desenvolvimento seja alcançado em sua máxima extensão. A ideia chave aqui é ver o desenvolvimento como resultante do impulso de forças complementares representadas pela riqueza de cada país obtida mediante seu direito à autodeterminação.

Tal como visto, a autodeterminação não se refere apenas a alguns aspectos da vida de um país, como os aspectos econômicos tradicionais, abrangendo também o poder de produzir uma riqueza cultural de forma autônoma. Por conseguinte a atuação complementar dessas forças dará origem à produção de uma verdadeira riqueza mundial, marcada por traços de pluralidade e diversidade.

Trata-se de verdadeira riqueza, pois apenas esse tipo de riqueza apresenta idoneidade para satisfazer as necessidades de todos os membros de uma sociedade cosmopolita emergente de uma nova ordem mundial. Com efeito, necessidades diversas exigem diversidade de riqueza para sua satisfação.

\section{A FUNÇÃO DO DIREITO COSMOPOLITA NO ESTABELECIMENTO DE UMA NOVA ORDEM MUNDIAL}

Rawls não vislumbra que possa existir uma relação entre os Estados similar à relação entre os cidadãos no âmbito interno. Todavia, alguns de seus proeminentes discípulos, como Charles Beitz e Thomas Pogge, afirmaram que existe sim uma relação entre os Estados similar àquela existente entre cidadãos dentro de um Estado, destacando-se o entendimento de Thomas Pogge, que asseverou ser essa uma relação de dominação.

Para especificar essa relação, Pogge contestou a crença de Rawls de que a radical desigualdade existente entre os países ricos e pobres pode ser explicada por circunstâncias como cultura, clima, instituições sociais internas, corrupção interna, afirmando que isso são efeitos de causas históricas:

Muito disso foi construído na era colonial, quando os países desenvolvidos de hoje governavam as regiões pobres de hoje, negociando as pessoas como gado, destruindo suas instituições políticas e cultura, tomando suas terras e recursos naturais e impondo seus produtos e costumes. ${ }^{7}$ 
Considera-se que esse argumento histórico de Pogge não pode ser entendido como sua maior contribuição para a criação de uma nova ordem mundial, de caráter cosmopolita, fundada na justiça. Com efeito, Pogge tem o mérito de ser um dos poucos filósofos políticos contemporâneos que percebeu que as vantagens que as nações hoje desenvolvidas obtiveram por meio da violência desde a época colonial foram mantidas por meio da construção de uma ordem internacional injusta: "Nós estamos preservando nossas grandes vantagens econômicas por meio da imposição de uma ordem institucional que é injusta (...). Há uma ordem institucional compartilhada que foi feita pelos países ricos e imposta aos países pobres. ${ }^{8}$

O importante filósofo adverte que poderia ser construída uma estrutura institucional alternativa na qual "a severa e extensiva pobreza não persistiria” (Pogge, s.d.), e destacou o fato de que muitas pessoas não levam em conta os fatores institucionais em suas análises da sociedade, o que se é um grave erro para um filósofo, é algo inadmissível para um economista, e “intolerável” para um jurista:

Gratos com a desatenção de nossos economistas, muitos acreditam que a ordem institucional global existente não contribui para a persistência da severa pobreza, mas que os fatores nacionais são a questão-chave. (...) Contudo, uma vez que nós abandonamos esse nacionalismo explicativo, é fácil encontrar fatores globais relevantes para a persistência da pobreza. ${ }^{9}$

Como exemplo de má distribuição de direitos e deveres realizada pelas atuais instituições internacionais, Pogge menciona, inter alia, o fato de que nas negociações da Organização Mundial do Comércio (OMC) os países ricos insistem em manter um estado de protecionismo em benefício de seus produtos, ao mesmo tempo em que pregam o discurso do livre mercado para os países pobres, o que denota sua hipocrisia (Pogge, s.d.).

Esse autor afirmou ainda que ao mesmo tempo em que os países ricos impõem uma proteção excessiva aos direitos referentes à propriedade intelectual, recebendo bilhões por isso, eles não querem recompensar os pobres pelas externalidades que causam por meio de sua "vasta e desproporcional contribuição à poluição global” (Pogge, s.d.).

Pogge destacou que os países ricos importam recursos naturais dos países pobres independentemente de o governo desses últimos ser corrupto, ditatorial, genocida, etc., e que as nações ricas vendem armas para as governadas por ditadores, ajudanda-as a manter seu poder com base na violência. Em síntese, os países ricos compram recursos de qualquer governo ditatorial, concedendo-lhes empréstimos, armas e tudo o mais de que precisem para manter seu controle ilegítimo sobre populações oprimidas (Pogge, s.d.).

Isso para não falar de alguns casos, tal como o ocorrido no Brasil, quando os Estados Unidos financiaram o golpe de Estado promovido pelos militares em 1964, 
a fim de obter privilégios que durante muitos anos nos levaram à ruína. Ademais, deve-se mencionar que os Estados ricos normalmente não agem dessa forma em benefício direto de suas populações, ainda que estas sejam beneficiadas indiretamente, tal como denota Pogge, mas no interesse de grandes grupos econômicos, ou seja, no interesse do soberano "supraestatal privado difuso" (Capella, 1997, p.10ss).

Pode-se afirmar que as instituições internacionais não apenas foram constituídas de modo a favorecer os países ricos, mas que também mantêm um funcionamento a fim de preservar uma relação assimétrica entre os Estados, com prejuízo direto para a população dos países pobres. Do mesmo modo que no âmbito interno os cidadãos são dependentes uns dos outros, entre os Estados existe essa mesma relação, o que contemporaneamente se apresenta de forma clara.

Há, todavia, uma situação específica não abordada por Pogge, na qual essa relação de interdependência se apresenta de forma inequívoca, sendo esse contexto, no que se refere ao aspecto institucional, um dos mais importantes, talvez o fundamental, para se compreender como alguns países conseguiram construir sua riqueza a custa dos países pobres. Trata-se do sistema monetário internacional, cuja constituição e desenvolvimento confirmam os argumentos aludidos por Pogge, no sentido de que o desenho das instituições internacionais é responsável pelo subdesenvolvimento, bem como confirmam uma das premissas deste trabalho no sentido de que as relações entre os Estados nacionais são relações de interdependência assimétrica responsáveis por causar extrema miséria para a maior parte dos membros da família humana.

Cumpre verificar como se desenvolvem as relações de poder no âmbito internacional, relacionando-as com o processo de desenvolvimento do sistema monetário internacional.

\section{I O PODER E O DINHEIRO NO ÂMBITO INTERNACIONAL: ASPECTOS TEÓRICOS}

Tradicionalmente, no âmbito das relações internacionais, o poder estatal sempre esteve associado à existência de recursos naturais e à força militar. Não obstante, nas sociedades contemporâneas complexas que se relacionam por meio do Direito e de outras instituições, como o dinheiro, o poder pode ser entendido também como uma propriedade relacional e estrutural que surge tanto das relações entre os Estados quanto da posição que um Estado ocupe no sistema internacional considerado como um todo.

Essa nova análise do poder, em seu aspecto relacional, é atribuída ao economista Albert Hirschman que, ao estudar as relações comerciais do Estado nazista com seus vizinhos, verificou que relações de dependência e dominação podem surgir naturalmente a partir de assimetrias no comércio internacional (Cohen, 2009, p. 23).

Posteriormente, Keohane e Nye enfatizaram que após a $2^{\mathrm{a}}$ Guerra Mundial as nações se tornaram cada vez mais dependentes umas das outras, embora tal relação 
de dependência raramente fosse simétrica (Cohen, 2009, p. 23). Caso a interação entre os Estados acontecesse de forma assimétrica, tal assimetria seria responsável por colocar um país sob o domínio do outro:

Mais precisamente o poder emerge das relações assimétricas de interdependência entre sujeitos estatais em diferentes áreas temáticas, mediante a criação de oportunidades para que os atores menos dependentes manipulem em proveito próprio os vínculos existentes (Álvares, 2009, p. 53).

Por outro lado, autores como Kenneth Waltz começaram a destacar em seus trabalhos a existência de uma distinção entre os aspectos relacionais e estruturais, sendo estes partes importantes para a distribuição de poder entre os agentes no âmbito internacional (Keohane, 1986, p. 71ss).

Um sistema, como o sistema monetário internacional, por exemplo, pode ser concebido como composto de uma estrutura e de partes interagindo. Contudo, embora a estrutura e as partes sejam conceitos relacionados, eles não são idênticos aos integrantes reais do sistema, pois, tal como afirmado por Waltz, a estrutura não é algo que possamos ver (Keohane, 1986, p. 72).

É fácil entender isso, porque os Estados que integram o sistema monetário nacional e as regras que definem a posição desses Estados no sistema não podem ser vistos como as pessoas e as riquezas naturais que compõem o Estado. Não obstante, tal como será visto, esses aspectos institucionais invisíveis podem influenciar sobremaneira a realidade natural, sobrepondo-se a esta muitas vezes.

O sistema monetário, por exemplo, é um setor da economia no qual a existência de uma assimetria institucional passa a ser responsável por definir a maior parte da situação de riqueza ou pobreza das nações. Tal como explica Cohen, nas sociedades contemporâneas "as economias nacionais estão conectadas por meio do balanço de pagamentos", ou seja, "o superávit de um país corresponde ao déficit de outro e vice versa [sic], sendo que o risco de um desequilíbrio insustentável representa uma persistente ameaça à independência política”. ${ }^{10}$

A partir desse novo contexto, buscou-se um novo modelo teórico de análise que fosse adequado a descrever as interações e relações de interdependência monetária entre as nações soberanas. Nesse modelo - buscado na moderna sociologia e chamado de análise de rede social social network analysis -, uma nação soberana pode ser compreendida como sendo um nó (node) conectado a outra nação, ou seja, a outro nó, que, por sua vez, conecta-se a outro, dando origem a uma vasta e complexa rede monetária formada por nações que se conectam por meio do balanço de pagamentos.

Essas relações adquirem um caráter de interdependência porque problemas num dos nós podem gerar problemas em outro, devendo-se observar que tal suposição do 
modelo apresenta forte comprovação empírica, pois uma crise financeira de um país é facilmente transmitida aos seus vizinhos, podendo se tornar uma crise internacional, da rede como um todo.

Se essas relações de interdependência acontecem de forma simétrica, ter-se-á uma situação de cooperação entre as nações, implicando a existência de um sistema financeiro internacional estável. Caso tais relações de interdependência aconteçam de modo assimétrico, ter-se-á uma situação de desigualdade entre as nações, com a submissão de um nó ao domínio de outro.

Uma vez constituída a rede, tal assimetria não dependerá dos atributos individuais do nó, tal como os reais fundamentos de sua economia, mas da posição que esse nó assuma na rede. Daí se falar que o poder numa rede não se vincula a questões naturais, portanto não se configura uma propriedade relacional, mas, sobretudo, estrutural.

As relações entre os nós, por sua vez, são constituídas por meio de regras institucionais que estabelecerão padrões de conexão das quais emanará o poder relacional, responsável pelo desenvolvimento da rede. Esse desenvolvimento poderá se dar conforme as relações de interdependência simétrica ou assimétrica.

É possível, contudo, que após a constituição de uma rede as relações de interdependência assimétrica fiquem arraigadas no corpo social a ponto de fazer com que, mesmo após o abandono das regras de conexão por um dos nós, os outros continuem a se conectar da mesma forma em relação a ele, tendo em vista o fato de que o poder outrora sustentado por normas jurídicas ter se transformado num poder econômico autossuficiente, uma vez que os nós já absorveram aquelas relações como naturais ao sistema, embora isso não seja verdade.

O que importa é que a ilusão da suposta naturalidade dos padrões de conexão já é suficiente para que o nó desertor consiga exercer seu domínio sobre os outros nós, adquirindo cada vez mais poder e riqueza, sem precisar se submeter a qualquer restrição de ordem institucional, como uma regra semelhante à criada em Bretton Woods, que obrigava os Estados Unidos a converter os dólares que lhe fossem apresentados pelos outros Estados em ouro.

Ocorre que todo processo de exploração não pode durar indefinidamente, ainda que o tempo durante o qual se desenvolva possa ser suficiente para enriquecer o país desertor jogando o restante do mundo na mais completa pobreza derivada de uma interdependência assimétrica.

Essa foi, em síntese, a exposição dos aspectos teóricos do modelo. Cabe saber agora como um país poderia ocupar uma posição de dominação frente outros países, ou seja, como é possível estabelecer relações de interdependência assimétrica em benefício próprio. Ou ainda como isso poderia ser feito por meio do sistema monetário internacional.

Deve-se responder a essas questões objetivamente. Um país pode estabelecer relações de interdependência assimétrica em seu próprio benefício por meio da 
internacionalização de sua moeda. No entanto, tal como afirmado, essa situação de dominação não pode se perpetuar indefinidamente, embora o tempo nesse caso prejudique mais os povos dominados.

Cabe saber também como seria possível fazer com que o sistema monetário internacional se desenvolvesse segundo relações de interdependência simétricas caracterizadoras de um real estado de cooperação internacional. Igualmente, aqui também cabe a objetividade: por meio da implantação de uma moeda única mundial, e não por meio da internacionalização de alguma moeda nacional.

Em outros termos, enquanto a internacionalização significaria conflito entre vários países - cada um querendo ocupar uma posição de dominação -, ao escolherem implantar uma moeda única mundial, eles estariam optando pela cooperação e estabilidade, transformando o dinheiro - que representa uma das principais causas da injustiça no mundo -, num meio da criação de justiça e prosperidade.

Da mesma forma que o cosmopolitismo torna o homem senhor do Estado, a moeda mundial tornaria o homem senhor do dinheiro. Todavia, essas são apenas respostas, sendo necessário justificá-las.

\subsection{A moeda mundial Como instrumento de PAZ, JUSTiÇa E Liberdade}

Apenas num estágio muito rudimentar das civilizações o dinheiro foi um fato natural e num período imediatamente posterior passou a ter sua existência vinculada a normas de cunho social estrito. Tal como explicado por Carl Menger (1981, p. 262263), o dinheiro surge como um produto do mercado, ou seja, na medida em que um determinado objeto passa a ser desejado por um grande número de pessoas num determinado contexto social esse objeto pode ser facilmente trocado por outros ou, em seus termos, passa a adquirir "vendabilidade".

A explicação para o gado ter sido dinheiro na antiguidade estaria associada ao fato de esse animal ser amplamente valioso naquele contexto. A "vendabilidade" apontada por Menger, que, mutatis mutandis, equivale ao que modernamente se denomina liquidez, é um valor distinto do valor de uso do objeto.

Nesse contexto de escambo, em que pese o fato de o gado ter um valor intrínseco de uso, a possibilidade de trocá-lo por outros objetos também necessários para a satisfação das necessidades humanas atribui a ele um valor autônomo, o valor de troca, conhecido apenas de um modo intuitivo, porém não científico, pelas civilizações rudimentares.

Essa falta de cientificidade conduziu as civilizações ao cometimento de diversos erros, sendo um dos principais o de confundir um objeto que passou a ser dinheiro pela possibilidade de ser utilizado para adquirir uma ampla diversidade de bens, ou seja, para adquirir riqueza com a riqueza que tinha a função de adquirir.

O exemplo mais lastimável dessa situação de ignorância a que estavam imersas as civilizações foi o metalismo. Coube a Adam Smith (1983, p. 262) desfazer o equívoco 
e demonstrar que a riqueza das nações não era o ouro, mas a produção. Coube ao mesmo filósofo moral demonstrar que, num sistema de papel-moeda parcialmente lastreado em ouro, uma emissão de dinheiro superior às necessidades da economia poderia causar uma quebra generalizada dos bancos, uma vez que, ao perceberem que a quantidade de papel-moeda emitida seria superior à quantidade de riqueza que essa moeda poderia fazer circular num determinado país, as pessoas correriam aos bancos para trocar o papel por ouro, a fim de utilizar este para importar produtos de outras nações.

A quebra desse sistema financeiro seria decorrência do fato de que o funcionamento dos bancos depende da crença de que as pessoas não sacarão o seu dinheiro ao mesmo tempo, pois se o fizerem, com toda certeza, os bancos não terão como atender a demanda, haja vista que trabalham segundo o sistema de reservas fracionárias. ${ }^{11}$

Muitos talvez não saibam quais são as vantagens de se utilizar um sistema de papel-moeda. A explicação oferecida por Smith é que esse sistema permite ao empreendedor que utilize uma riqueza que de outra forma deveria permanecer guardada para atender situações inesperadas. Ou seja, em vez de utilizar certa quantidade de ouro para contratar empregados e aumentar a produção, o empreendedor tinha que mantê-la parada por causa das incertezas do processo produtivo.

Para Smith (1983, p. 277) o papel-moeda emprestado pelos bancos permitia que a riqueza parada se tornasse uma riqueza produtiva, desde que só se emprestasse aos empreendedores a quantidade de papel-moeda equivalente à quantidade de riqueza que de outro modo eles deveriam manter como riqueza improdutiva.

O papel-moeda ao qual Smith se referia significava dinheiro parcialmente lastreado em ouro, e não dinheiro sem lastro, tal como é nos dias de hoje. Esse lastro, no entanto, era parcial e, de acordo com Smith, deveria servir como uma espécie de "freio" (ele não utiliza esse termo) na vontade dos banqueiros de emprestar dinheiro. Segundo o filósofo e economista escocês, se os bancos procurassem realmente os seus próprios interesses jamais iriam emprestar um valor superior, para os empreendedores, àquele que sem a existência do papel-moeda deveria permanecer guardado como riqueza improdutiva.

Caso o contrário fosse feito, esse dinheiro excedente voltaria rapidamente para os bancos, que por trabalharem num sistema de reservas fracionárias não teriam como atender a essa demanda inesperada, não teriam como converter o dinheiro apresentado em ouro. O resultado seria uma corrida bancária que produziria o colapso do sistema.

No que se refere às consequências de uma emissão de papel-moeda excessiva para causar um déficit no balanço de pagamentos. É fácil perceber que o dinheiro em excesso provocaria uma elevação dos preços internos e da renda nominal, o que, como se sabe, provocaria um aumento das importações, pois uma parte da renda é destinada ao consumo interno, outra, à poupança e outra, à importação. 
Quando os exportadores fossem trocar a moeda estrangeira por ouro - o que gradativamente passou a ser uma atribuição dos bancos centrais -, o país do importador não teria ouro suficiente, pois permitiu uma emissão de papel-moeda acima das necessidades da economia, embora os defensores radicais de um sistema totalmente lastreado afirmem que bastaria uma emissão parcialmente lastreada para esse processo ser desencadeado. Ademais, o aumento dos preços internos por certo também contribuiria para a redução das exportações e aumento do déficit (Rothbard, s.d.).

O resultado, em última instância, seria ou a deflagração de um processo inverso, ou seja, de deflação por parte do Estado inflacionário, o que não seria bem visto pelo povo e pelos políticos de um modo geral por implicar corte de gastos, ou o abandono da conversão da moeda em ouro, retirando o freio que impede o crescimento desmedido de um processo inflacionário.

Tal lógica foi sendo confirmada no decorrer da história. A $1^{\text {a }}$ Guerra, iniciada em 1914, pôs fim ao padrão-ouro internacional, pois as despesas de guerra obrigaram os países a emitir moeda para financiá-las, o que causou um grande processo inflacionário e colocou o sistema financeiro internacional num grande caos. Durante esse período o câmbio era flutuante e os países estavam imersos numa guerra cambial marcada por uma constante desvalorização de suas moedas para conseguir preços competitivos no mercado internacional.

Diante desse cenário caótico, os países decidiram retornar ao padrão-ouro. A Grã-Bretanha, todavia, para manter seu prestígio internacional sobrevalorizou a libra em relação ao ouro, o que lhe trouxe graves problemas econômicos durante a década de 1920, uma vez que isso deprimiu suas exportações (Rothbard, s.d.).

Para impedir que circunstâncias econômicas retirassem seu poder político, a Grã-Bretanha decidiu utilizá-lo a fim de promover uma reformulação do sistema monetário internacional em seu benefício (Rothbard, s.d.). Essa reformulação foi realizada na Conferência de Gênova em 1922.

Nessa Conferência foi estabelecido o chamado padrão ouro-câmbio. De acordo com esse padrão, os Estados Unidos, que durante a $1^{\text {a }}$ Guerra não haviam abandonado o padrão-ouro clássico, permaneceriam nesse sistema. Por outro ladro, as libras só seriam convertidas em ouro em grandes barras, limitando essa conversão às transações internacionais (Rothbard, s.d.).

Relembrando os ensinamentos de Smith, o primeiro obstáculo imposto pelo padrão-ouro àquelas tendências inflacionárias havia sido retirado, pois em caso de uma emissão de moeda em excesso, mesmo que os cidadãos britânicos comuns quisessem trocar esse excedente por ouro com o fim de importar, não poderiam, sendo, portanto, obrigados a permanecer com uma quantidade de dinheiro desprovida de valor real.

Segundo os ensinamentos de Smith, isso deveria resultar na quebra dos bancos e aumento dos preços internos. O outro obstáculo seria externo, qual seja, encontrar 
uma forma de impedir que os exportadores estrangeiros trocassem as libras recebidas de suas transações comerciais com os britânicos por ouro, uma vez que os altos preços internos ocasionados por emissões inflacionárias resultariam num déficit no balanço de pagamentos e na consequente diminuição das reservas auríferas da Grã-Bretanha.

Esse problema também foi resolvido na Conferência de Gênova, uma vez que, em vez de trocarem as libras por ouro, os outros países deveriam manter grande parte de suas reservas em libras. Além disso, o governo inglês poderia não apenas converter as libras em ouro, mas também em dólares, que permaneceriam vinculados ao ouro. Esse novo contexto transformava o sistema monetário numa pirâmide: na base estavam as diversas moedas atreladas a uma das moedas-chave dessa pirâmide, a libra. Por sua vez, a libra estaria atrelada ao dólar que permanecia atrelado ao ouro, funcionando como a outra moeda-chave do sistema (Rothbard, s.d.).

Caso os países cujas moedas formavam a base da pirâmide decidissem inflacionar em relação à libra, eles teriam de ajustar o consequente déficit no balanço de pagamentos causado pelo processo inflacionário, uma vez que sem libras não poderiam atuar no mercado internacional. Para ajustar o déficit teriam basicamente que aumentar as exportações e cortar gastos.

O mesmo não acontecia com a Grã-Bretanha que poderia ajustar o seu déficit por emissão monetária, ou seja, tinha o privilégio de pagar suas dívidas internacionais com a própria moeda, o que lhe traria imensos benefícios econômicos devidos principalmente aos ganhos de senhoriagem. ${ }^{12}$ Além disso, a Grã-Bretanha possuía condições vantajosas de negociação com os credores, pois num sistema em que ter libras era fundamental para adquirir estabilidade econômica todos estariam dispostos a conceder crédito aos ingleses. ${ }^{13}$

Esses privilégios, contudo, não poderiam ser sustentados indefinidamente, o que não impediria, contudo, que a desigualdade econômica existente durante esse período provocasse a falência dos países que formavam a base da pirâmide monetária e acentuasse a supremacia política e econômica dos países que estivessem no topo.

Igualmente, a eventual quebra do sistema não afetaria unicamente a nação que abusou de seus privilégios, mas todas, sobretudo, num sistema econômico em que, tal como apontado por Benjamin Cohen (2009, p. 20), "as economias nacionais estão inescapavelmente conectadas através do balanço de pagamentos”.

No caso do sistema ouro-câmbio, estabelecido pela Conferência de Gênova, quanto mais os países acumulavam libras que crescentemente perdiam seu valor, mas se desconfiava da capacidade da Inglaterra de honrar seu compromisso de trocar libras por ouro, temendo-se o resultado da constante desvalorização da libra para as reservas internacionais. Assim, quando a França decidiu trocar suas libras por ouro, a Inglaterra foi forçada a abandonar esse sistema (Rothbard, s.d.). Portanto, embora durante algum tempo os ingleses tivessem conseguido postergar o acerto das contas, tirando benefício disso, o dia fatal havia chegado. 
O resultado da quebra do sistema foi uma desestabilização do sistema financeiro internacional, que voltou a funcionar segundo um regime de câmbio flutuante com uma intensa guerra cambial entre os países, promovida por meio de desvalorizações artificiais que, segundo Cordell Hull, Secretário de Estado norte-americano, teria sido a principal causa da $2^{a}$ Guerra Mundial (Rothbard, s.d.).

O caos mais uma vez estava instaurado e, mais uma vez, os Estados, após um grande período de turbulências, tiveram a oportunidade de estabelecer um sistema monetário equitativo entre as nações soberanas na Conferência de Bretton Woods. Duas foram as propostas apresentadas: uma americana e outra inglesa. A proposta americana pretendia instaurar um sistema similar ao estabelecido na Conferência de Gênova, com a diferença de que o dólar seria a única moeda-chave vinculada ao ouro. As outras moedas estariam vinculadas ao dólar, cabendo ao Fundo Monetário Internacional (FMI) zelar para que as taxas de câmbio entre as moedas-base permanecessem estáveis em relação à moeda americana, que, por sua vez, deveria permanecer estável em relação ao ouro.

As taxas de câmbio, por certo, poderiam ser ajustadas sempre que fosse demonstrada a existência de transformações no lado real da economia, evitando-se, portanto, desvalorizações artificiais. Por outro lado, o FMI poderia ajudar países deficitários que tivessem problemas contingenciais, de modo a preservar o sistema estabelecido (Carvalho, s.d.).

Tal proposta idealizava o funcionamento de um sistema monetário internacional com dois problemas essenciais.

\subsection{A moeda mundial E O Fim do PRivilégio eXorbitante}

O primeiro problema era que nesse sistema os Estados Unidos teriam o que Valéry Giscard d'Estaing chamou em 1960, de "um privilégio exorbitante consistente na faculdade de financiar suas transações correntes com o restante do mundo mediante emissão monetária própria e de financiar suas necessidades orçamentárias em condições vantajosas, em virtude da demanda por ativos denominados em sua moeda" (apud Alvares, 2009, p. 50).

A possibilidade de financiar suas transações correntes mediante emissão monetária própria significaria que, assim como ocorreu com a Grã-Bretanha durante o padrão ouro-câmbio, os Estados Unidos seriam o único país do mundo com a possibilidade de pagar suas dívidas internacionais utilizando a própria moeda. Isso proporcionaria os mesmos benefícios de senhoriagem desfrutados outrora pela GrãBretanha, que servem como grande incentivo para manter um déficit no balanço de pagamentos, política essa mantida até os dias de hoje pelos Estados Unidos.

Em termos simples, como o custo para fabricar um dólar é muito inferior do que um dólar vale, os Estados Unidos adquirem bens de outros países a um custo real extremamente baixo e muito menor do que o pago no mercado internacional. Com 
efeito, para o Brasil pagar uma dívida no valor de US\$ 500 milhões ele precisará produzir bens que possam ser vendidos no mercado internacional por US\$ 500 milhões, enquanto para os Estados Unidos pagarem uma dívida no mesmo valor bastará fabricar esse dinheiro, o que evidentemente terá um custo muito menor do que aquele arcado pelo Brasil.

Muitos, por certo, poderiam argumentar que, se os Estados Unidos abusassem desse privilégio, o dólar iria se desvalorizar em relação ao ouro, o que, por sua vez, poderia implicar perda de reservas que os obrigaria a adotar uma política econômica mais restritiva. Essa seria apenas uma das possibilidades. Com efeito, os Estados Unidos poderiam tanto exercer o seu poder político para que os outros países não trocassem suas reservas em dólar por ouro, tal como foi feito pela Grã-Bretanha, como poderiam seguir o exemplo desta num outro sentido, ou seja, abandonando seu laço com o ouro, a fim de continuar implementando uma política de gastos financiada por emissão monetária. A última opção foi a escolhida, e em 1971 o Presidente Nixon anunciou que estaria quebrando o acordo feito em Bretton Woods.

Seria ingenuidade, no entanto, pensar como Rothbard e atribuir o abandono dos Estados Unidos ao acordo simplesmente porque não teria mais capacidade de honrar seu compromisso de converter dólares em ouro. Ora, se os Estados Unidos tiveram poder político para descumprir um acordo tão importante para o sistema monetário internacional, como o acordo de Bretton Woods, sem sofrer qualquer represália internacional, foi porque tinham poder suficiente para impor "goela a baixo" seus dólares contra qualquer pretensão estrangeira de convertê-los em ouro.

A questão, por certo, é mais complexa, e se refere ao fato de os Estados Unidos terem adquirido uma posição de centralidade na rede monetária (Cohen, 2009, p. 25) que, embora tivesse sido fruto da constituição injusta do sistema monetário definido em Bretton Woods, era tida como um fato natural em 1971. Ou seja, havia acontecido o que foi dito na seção anterior quando foi exposto o modelo teórico das relações de poder no âmbito internacional. ${ }^{14}$

A análise de Rothbard desconsidera que o abandono dos Estados Unidos ao acordo não causaria nenhum ônus àquele país, pelo menos no curto prazo, mas apenas lhe atribuiria benefícios que lhe permitiriam se firmar como potência mundial (Carchedi, 1991, p. 278-279).

Em síntese, pode-se afirmar que a primeira vantagem que um país obtém ao internacionalizar sua moeda é poder importar produtos a um valor mais baixo do que os outros. Ele pode, por exemplo, comprar empresas em outros países, recursos naturais, e todo tipo de riqueza real imaginável, simplesmente ao custo de emissão de sua moeda. Esse benefício de senhoriagem somado ao fato de ter sua moeda como moeda de reserva internacional faz com que o dinheiro pago pelas riquezas dos outros países retorne ao país emissor sob a forma de investimento em títulos públicos do tesouro. Isso porque o dólar recebido por uma empresa chinesa que exporta 
algo para os Estados Unidos, por exemplo, é trocado por yuans com o Banco Central da China, que, por sua vez, investirá esses dólares principalmente em títulos do tesouro dos Estados Unidos. Isso ocorre com os outros países provocando uma diminuição dos juros nos Estados Unidos. Sim, porque, como se sabe, um aumento da procura por títulos aumenta o preço destes, significando uma diminuição da taxa de juros, dado que o preço dos títulos varia de modo inversamente proporcional à taxa de juros.

Essa queda dos juros tem reflexos tanto no âmbito interno quanto no externo. $\mathrm{Na}$ economia interna, em tese, com os juros baixos é possível aumentar o investimento e o consumo até o ponto de se atingir o pleno emprego. No âmbito externo, é possível ganhar com a arbitragem da taxa de juros. Se os Estados Unidos vendem um título para o Brasil devendo honrá-lo daqui um ano, por exemplo, nesse intervalo de tempo eles poderiam emprestar esse dinheiro numa taxa de juros suficiente para pagar o Brasil e ainda ter lucro.

Ocorre, contudo, que esse raciocínio é insuficiente para explicar o funcionamento do sistema atual, porque desconsidera a atuação do soberano privado. Com efeito, é insignificante a atuação direta dos Estados Unidos na economia por meio de bancos públicos ou empresas estatais. Na prática, esse país depende da arrecadação tributária e precisa que os agentes privados constituam empresas no seu território para que sua população tenha emprego. Todavia, os agentes privados ao ter acesso a uma taxa de juros baixa no mercado financeiro norte-americano não irão comprar empresas nos Estados Unidos, por causa dos altos salários, dos encargos trabalhistas e dos impostos sobre a renda. Eles irão constituir a matriz de suas empresas num paraíso fiscal para não pagar impostos (Parada Filho, 2009), e suas fábricas, principalmente nos países asiáticos, para desfrutar dos benefícios de mão de obra escrava, existente em algumas regiões de forma clandestina. Igualmente, comprarão títulos em países como o Brasil, no qual os juros são altíssimos.

Devido à abertura econômica da China, que aceitou submeter sua população à exploração capitalista, e devido à necessidade de países como o Brasil de aumentar os juros para obter reservas de dólares, os benefícios de senhoriagem e a flexibilidade macroeconômica que outrora atribuíam aos Estados Unidos o status de superpotência mundial foram sendo gradativamente transferidos para o soberano privado, que hoje assume posição predominante ao lado dos Estados nacionais, determinando, inclusive, as políticas destes.

Como o lucro dos investimentos do soberano privado vai parar num paraíso fiscal, em vez de render tributos para os Estados Unidos, sua única alternativa para sanar seus déficits impagáveis é por meio de emissão de moeda, que enriquece mais o soberano privado, empobrece os países que possuem reservas em dólar, e permite a criação de "bolhas financeiras" que não tardam em se transformar em crises financeiras internacionais que, por sua vez, prejudicam todo mundo. 
É claro que muitas outras questões poderiam ainda ser analisadas, como um estudo mais detalhado das vantagens econômicas e políticas oriundas da internacionalização de uma moeda nacional, o que, todavia, transcenderia os limites deste trabalho.

Com efeito, o objetivo deste trabalho consiste apenas em mostrar que a internacionalização de uma moeda coloca o país emissor desta numa posição de centralidade e superioridade no sistema monetário internacional, a qual é incompatível com o ideal de cooperação que pressupõe um sistema monetário fundado em relações de interdependência de natureza simétrica.

Pode-se afirmar que numa sociedade cosmopolita não denem existir privilégios, pois o inevitável abuso destes trará como consequência a crise e a pobreza, inclusive para aqueles que abusam de seu poder exorbitante, ainda que esses poucos homens, os quais não se eximem de cultuar a escravidão, não sejam tão vítimas da miséria financeira quanto a maioria dos membros da família humana. Inobstante, são vítimas da pior forma de miséria que existe: a miséria moral.

O abuso do privilégio de financiar déficits orçamentários por meio de emissão da própria moeda trará, mais cedo ou mais tarde, inevitáveis problemas não apenas para o país que abusa desse poder, mas para a própria estabilidade do sistema monetário internacional.

Urge reformular o sistema, implantando uma moeda mundial de reserva, em oposição à adoção de qualquer moeda internacional ou mesmo de alguma cesta de moedas, pois uma cesta de moedas internacionais apenas ampliaria o leque de países desfrutando de um privilégio exorbitante.

\subsection{A MOEDA MUNDiAl COMO MEIO DE COOPERAÇÃo}

É pertinente começar esta seção perguntando qual será nossa opção. Justiça ou conflito? A internacionalização de uma moeda ou cesta de moedas gera privilégios exorbitantes que causam o enriquecimento de uma pequena parcela da população à custa da miséria de muitos. Esses muitos são trabalhadores submetidos ao trabalho escravo, pequenos e médios empresários, vítimas de juros altos e de concorrência desleal, e todos aqueles que não têm acesso ao mercado financeiro do país que emite uma moeda internacional; não podem constituir empresas em países que não respeitam os mínimos direitos fundamentais do homem; não podem sonegar tributos com o uso de paraísos fiscais, ou realizar arbitragem com os juros internacionais.

Por outro lado, certo é que a China e o Brasil, por exemplo, não são os únicos culpados pelas condições dos trabalhadores ou pelas altas taxas de juros cobradas. Tais políticas são na verdade consequência de um sistema organizado de forma imperfeita, cujas deficiências são utilizadas hoje, sobretudo, pelo soberano privado, dado que mesmo os Estados Unidos já não se encontram numa posição muito favorável no cenário internacional. 
O resultado é que enquanto os Estados nacionais atualmente estão em conflito, havendo receio de que exista uma guerra cambial que pode inclusive resultar numa guerra militar, o soberano privado continua a enriquecer-se independentemente das políticas econômicas adotadas pelos Estados.

Enquanto houver disparidades no sistema monetário internacional ,sempre haverá possibilidade de realizar arbitragem. Enquanto existirem paraísos fiscais, grandes diferenças entre os Estados no que se refere à concessão de direitos trabalhistas e, principalmente, enquanto alguns países dispuserem de uma moeda internacional, sendo, por conseguinte, beneficiados por uma taxa artificialmente baixa de juros e por condições privilegiadas para financiar seus déficits no balanço de pagamentos, sempre haverá exploração, que, em última instância, representa a injustiça causadora de conflitos.

É necessário reconstruir a ordem econômica internacional para alcançar a estabilidade, e isso deve começar por meio da reconstrução do sistema monetário internacional, que é o ponto nevrálgico da sociedade capitalista.

Urge, portanto, transformar o sistema monetário internacional conflitante, que caracteriza a sociedade capitalista, num sistema monetário cooperativista, caracterizador de uma sociedade cosmopolita. Para isso, impende-se reformular as instituições internacionais, criando-se um banco central mundial que administre as reservas dos países de modo a acabar com o ajuste assimétrico do balanço de pagamentos, promovendo um sistema monetário internacional baseado em relações de interdependência simétrica.

\subsection{A função do Direito Cosmopolita na constituição de Uma nova ordem MUNDIAL REGIDA PELO PRINCÍPIO DA INTERDEPENDÊNCIA}

Ao contrário do que muitos possam pensar, a criação de um sistema monetário internacional desenvolvido segundo relações de interdependência simétricas, fundado numa moeda mundial administrada por um banco central mundial, não é uma proposta inovadora, tal como recentemente lembrou a presidenta do Brasil, Dilma Rousseff.

Com efeito, essa foi a proposta inglesa feita por John Maynard Keynes no acordo de Bretton Woods, a qual foi rejeitada por contrariar os interesses dos Estados Unidos, que na época estavam em posição de supremacia econômica. Infelizmente, a subordinação foi escolhida à cooperação, sem que o homem percebesse as consequências negativas disso para a humanidade.

Mesmo atualmente muitos ainda possuem uma mentalidade capitalista ultrapassada, voltada a subordinar os mais fracos. Isso está por detrás, por exemplo, da proposta do especulador Jorge Soros de substituir o dólar por uma cesta de moedas. Isso seria uma medida paliativa, inadequada a prover um sistema monetário internacional estável.

O segundo problema essencial da proposta americana, que também não seria alterado por meio da adoção de uma cesta de moedas de reserva, é que a referida 
proposta não solucionaria o problema do ajuste assimétrico que joga todo o ônus do ajuste do balanço de pagamentos para os países deficitários, sem impor obrigação alguma aos superavitários (Carvalho, s.d.). Se a renda de um país cresce, cresce também aquela parte da renda destinada às importações, podendo provocar um déficit comercial no país que se encontra num processo de crescimento.

Num sistema econômico internacional voltado para a prosperidade, algumas coisas não podem ser aceitas como opções para solucionar o déficit causado pelo crescimento das importações. A primeira delas é a alta dos juros, pois, salvo em casos em que a economia esteja sendo forçada num ponto acima do pleno emprego, a alta dos juros limita o crescimento econômico de forma injustificada.

A segunda consiste na desvalorização da moeda para aumento das exportações, uma vez que isso prejudica os países vizinhos e pode causar uma guerra cambial que, tal como se falou alhures, foi um dos fatores considerados como causa da $2^{\text {a }}$ Guerra Mundial. O aumento de tributos impede a atualização do potencial econômico de um país, causando desemprego e pobreza.

Posto isso, qual seria a solução adequada à promoção da prosperidade internacional?

De plano, deve-se rejeitar a ideia da ortodoxia liberal de retornar ao padrãoouro. Isso porque a expansão da capacidade produtiva não pode ser restringida por um elemento exógeno sem relação com a atividade econômica e passível de ser manipulado pelos agentes privados. Não é a atividade econômica que deve se adequar aos meios de pagamento existentes, mas o volume dos meios de pagamento é que deve ser adequado ao desenvolvimento econômico.

Dever-se-ia, portanto, criar um meio de pagamento que não se confundisse com a moeda nacional de qualquer país, para evitar a existência de privilégios exorbitantes que causem uma diferença de oportunidades entre as nações e ocasionem injustiça por meio da desigualdade. Além disso, a disponibilidade desse meio de pagamento deveria adequar-se ao comércio internacional e não restringi-lo de modo injustificado, tal como acontece num sistema baseado no padrão-ouro. Ao contrário de impedir que nações em crescimento se desenvolvam, um sistema voltado à prosperidade internacional deveria permitir que todos pudessem crescer num sistema de cooperação, tal como consta na declaração sobre o direito ao desenvolvimento.

Todos esses fundamentos estavam presentes na proposta inglesa elaborada por Keynes. Para satisfazer o pressuposto de se ter um meio de pagamento com liquidez adequada ao desenvolvimento do comércio internacional, Keynes propôs a criação de uma câmara de compensações internacionais (International Clearing Union, ICU), que centralizaria todos os pagamentos referentes a exportações e importações de bens, serviços e ativos (Carvalho, s.d.). Os bancos centrais nacionais teriam reservas nessa câmara de compensação centralizando o mercado de câmbio. De modo similar ao que acontece atualmente com o Convênio de Créditos Recíprocos, uma operação de exportação envolveria o recebimento das receitas de exportação por um 
banco no país do importador, este repassaria o valor para o banco central de seu país, o qual, por sua vez, transferiria os recursos para a conta reserva pertencente ao banco central do país do exportador, finalizando-se a operação com o recebimento do valor da exportação pelo exportador.

Uma diferença importante entre a ICU proposta por Keynes e o CCR ou qualquer outra câmara de compensação é que a moeda de reserva não seria uma moeda nacional internacionalizada, como o dólar, mas uma moeda escritural não pertencente a qualquer nação soberana, mas a todas as nações, sendo, portanto, uma moeda mundial (Carvalho. s.d.).

Essa moeda chamada por Keynes de "bancor" seria apenas transacionada no âmbito da ICU, que, como autoridade monetária, poderia emiti-la dependendo das necessidades do comércio internacional. Em outras palavras, o sistema monetário seria um instrumento em prol da economia real, e não uma fonte de especulação que a destrói. Tendo em vista que o bancor não pertenceria a nenhum Estado soberano, nenhuma nação gozaria dos privilégios exorbitantes de senhoriagem no âmbito internacional nem de condições desiguais de financiamento ocasionadas pela criação de uma demanda artificial por seus ativos. Essa flexibilidade macroeconômica que Benjamin Cohen (2009, p. 29) considera um importante elemento de autonomia e poder para o país que emite uma moeda internacional não mais existiria, ou pelo menos não seria gerada por condições artificiais sem nexo com os fundamentos econômicos.

Mais importante ainda é que a proposta de Keynes permitiria que todos os países crescessem num sistema de cooperação e de proveito mútuo. Para realizar esse intento, Keynes propôs que, em vez da imposição de restrições injustificadas aos países em crescimento, dever-se-ia corrigir os déficits desses países com o superávit dos países que estivessem mantendo sua economia abaixo do pleno emprego, para fazer com que os superavitários também pudessem crescer.

Tal como foi afirmado, os Estados Unidos abusaram dos exorbitantes privilégios que lhes foram concedidos em Bretton Woods, e ampliaram sua exorbitância de forma unilateral em 1971, quando quebraram a palavra empenhada. De superavitários passaram a conviver com grandes déficits, enquanto países como a China acumulam superávits. O FMI, que outrora pressionava apenas os países deficitários, agora se rende à proposta de Keynes no sentido de pressionar os superavitários a importar (IMF, 2010).

Por que só agora o FMI mudou? Seria melhor que tivesse mudado antes, embora, se diga no cotidiano: "Antes tarde do que nunca"?

A proposta keynesiana assume especial destaque no atual contexto, tendo em vista os resultados adversos da crise econômica para a criação e manutenção do pleno emprego. Segundo a doutrina preconizada por Keynes, em momentos de incerteza a poupança tende a se acumular, havendo redução da demanda efetiva. Hoje seria essencial que países superavitários como a China diminuíssem seus superávits em prol do bem-estar de países que passam por dificuldades. Não obstante, será que o modo 
como o sistema monetário internacional está organizado serve de incentivo para o aumento do consumo externo chinês? Quem garante que, se a China e os demais países superavitários começarem a incentivar as importações, os Estados Unidos, assim que recuperarem seu crescimento, não tornarão a abusar de seus exorbitantes privilégios? É muito difícil que os superavitários adotem uma postura de cooperação sem que seja construído um novo sistema monetário justo e voltado à prosperidade, de um modo semelhante ao idealizado por Keynes.

Enquanto o sistema não for reformulado, não haverá incentivos para a cooperação internacional, permanecendo a instabilidade, que inevitavelmente gerará crises cada vez maiores. A construção de um sistema monetário justo está exclusivamente nas mãos dos governantes, e dependem exclusivamente de sua vontade, pois as transformações requeridas são de cunho institucional.

$\mathrm{Ou}$ a humanidade muda seus valores competitivos e hierárquicos em prol dos valores da cooperação e interdependência por vontade própria, ou terá de mudar por meio do sofrimento gerado pela guerra e pela pobreza. É preciso ser realista e admitir que dentro da visão de curto prazo que infelizmente ainda reina na política econômica internacional não há incentivos para que as nações beneficiadas pelos referidos processos assimétricos se esforcem para construir um sistema econômico simétrico e mais justo. Por meio de uma conscientização da sociedade civil acerca dos benefícios de se construir um projeto de longo prazo talvez seja possível influenciar os políticos e impedir que estes mantenham o processo cíclico vicioso que, tal como se vê nos dias atuais, tem lançado no desemprego a população dos Estados Unidos e de alguns países da Europa, que outrora eram beneficiados pelas assimetrias econômicas internacionais.

\section{CONCLUSÃO}

A justiça social entre os cidadãos dos Estados nacionais e a justiça entre os povos é a única forma de o homem atingir a paz. Por outro lado, não é possível estabelecer a justiça no âmbito interno sem que exista justiça entre os povos, pois os países, da mesma forma que os cidadãos de um Estado nacional, são interdependentes. Infelizmente, o cultivo de valores como o da concorrência característica do capitalismo e o da hierarquia compartilhada tanto pelo capitalismo quanto pelo comunismo, tornou as relações de interdependência entre os seres humanos assimétricas, gerando miséria, conflitos sociais, guerras, objetivação do ser, confusões entre o ser o ter e, sobretudo, a substituição do amor a si e ao próximo por um egoísmo infrutífero causador de ruína e infelicidade.

Seria preciso construir uma nova realidade social, substituindo esses valores anacrônicos pelos da tolerância, da liberdade individual, da autodeterminação dos povos, da cooperação, do proveito mútuo, de modo a transformar a assimetria em simetria 
nas relações de interdependência entre os membros da família humana. Para que isso seja possível, é preciso reconstruir não apenas a estrutura básica interna dos Estados nacionais, mas a estrutura básica da sociedade internacional, uma vez que o poder dos Estados entendidos isoladamente não pode superar o poder assimétrico causador de injustiça que emerge das relações de interdependência entre as unidades constitutivas do sistema internacional.

A violação dos direitos humanos na África e na Ásia, por exemplo, não pode ser atribuída apenas a países desses continentes, pois embora eles violem esses direitos de forma direta, a responsabilidade por essas violações é de todo sistema internacional, tal como percebeu Thomas Pogge. Esse sistema internacional, por sua vez, não pode ser reduzido apenas aos Estados e organizações internacionais, uma vez que os agentes privados representados pelas grandes empresas transnacionais possuem poder semelhante a essas instituições, não raro, determinando a política dos Estados.

Nesse contexto surge o Direito Cosmopolita como instrumento para alcançar a paz por meio da justiça. Entre os seus fundamentos está o princípio da tolerância, que é a resposta para os problemas gerados pelas diferenças de ordem cultural e religiosa existentes tanto no âmbito interno dos Estados quanto no âmbito internacional. O princípio da tolerância do Direito Cosmopolita leva a liberdade individual e a diversidade de formas de vida a sério, respeitando todas as manifestações existenciais, desde que não sejam impostas aos seres humanos. Nesse sentido, cada um é senhor apenas de si próprio e jamais senhor do próximo. Isso vale para as relações entre os indivíduos em sua esfera privada e para as relações entre os indivíduos e o Estado, e para as relações entre os próprios Estados.

O teórico do Direito Cosmopolita assume uma função mais complexa e sofisticada do que o tradicional teórico positivista, que se ocupa apenas da leitura superficial dos textos jurídicos. O teórico do Direito Cosmopolita deve analisar o Direito consoante sua referida função, o que lhe trará o encargo da interdisciplinaridade e a satisfação de dialogar com seus amigos filósofos, sociólogos, economistas, e com o povo de modo geral, sempre buscando medidas que possam ser transformadas em leis, a fim de construir ou reformar instituições no sentido da justa distribuição de direitos e deveres, eliminar o conflito e atingir a paz perpétua.

$\mathrm{Na}$ contemporaneidade, uma das medidas necessárias para alcançar a justiça entre os povos, impedindo a possibilidade de uma catastrófica terceira guerra, seria o estabelecimento de uma moeda mundial de reserva. O estabelecimento dessa moeda, dar-se-ia consoante os fundamentos do Direito Cosmopolita que se encontram positivados em vários documentos internacionais, como a Carta das Nações Unidas, a Declaração da Organização das Nações Unidas sobre o Direito ao Desenvolvimento, a Declaração sobre os Princípios da Tolerância, entre outros.

A proposta de Keynes, elaborada muito antes do surgimento da Declaração sobre o Direito ao Desenvolvimento e do Pacto Internacional dos Direitos Econômicos, 
Sociais e Culturais, e rejeitada no acordo de Bretton Woods, adéqua-se a muitos dos fundamentos do Direito Cosmopolita contidos nesses documentos, pois possibilita a construção de um sistema monetário internacional fundado no princípio da interdependência, da cooperação e do proveito mútuo.

Caberia aos economistas verificar até que ponto essa proposta poderia ser melhorada, para se adequar ao atual contexto econômico; e caberia ao jurista cosmopolita verificar até que ponto uma proposta de reforma do sistema monetário internacional se adéqua aos seus fundamentos de justiça, que pudessem ser considerados normas de jus cogens.

Urge reconstruir as estruturas institucionais segundo princípios de justiça cosmopolita, para se conseguir uma nova ordem mundial que promova a paz e elimine a pobreza, trazendo todos os membros da família humana para uma nova vida de unidade em meio à diversidade.

: ARTIGO APROVADO (08/12/2011) : RECEBIDO EM 07/05/2011

NOTAS

1 Cf. Rawls (1971).

2 Na busca por meios de se implantar um estado de paz perpétua, de destaque foi um dos trabalhos de Kant (2006, p. 57), em que o autor afirmava: "Não deve considerar-se válido nenhum tratado de paz que tenha sido celebrado com a reserva secreta sobre alguma causa de guerra no futuro. Tratar-se-ia, neste caso, simplesmente de um mero armistício, uma prorrogação das hostilidades, não da paz, que significa o fim de todas as hostilidades”.

3 No artigo $1^{\circ}$ dessa Declaração (1995), a tolerância é definida como "o respeito, a aceitação e o apreço da riqueza e da diversidade das culturas de nosso mundo, de nossos modos de expressão e de nossas maneiras de exprimir nossa qualidade de seres humanos. É fomentada pelo conhecimento, a [sic] abertura de espírito, a [sic] comunicação e a [sic] liberdade de pensamento, de consciência e de crença. A tolerância é a harmonia na diferença. Não só é um dever de ordem ética; é igualmente uma necessidade política e jurídica. A tolerância é uma virtude que torna a paz possível e contribui para substituir uma cultura de guerra por uma cultura de paz" (grifo nosso).

4 O artigo terceiro da Declaração (1896) expressa que "Os Estados têm o dever de cooperar uns com os outros para assegurar o desenvolvimento e eliminar os obstáculos ao desenvolvimento. Os Estados deveriam realizar seus direitos e cumprir suas obrigações de modo tal a promover uma nova ordem econômica internacional baseada na igualdade soberana, interdependência, interesse mútuo e cooperação entre todos os Estados, assim como a encorajar a observância e a realização dos direitos humanos" (grifo nosso).

5 O artigo primeiro do Pacto (1992) é muito elucidativo: “... todos os povos têm direito à autodeterminação. Em virtude desse direito, determinam livremente seu estatuto político e asseguram livremente seu desenvolvimento econômico, social e cultural. Para a consecução de seus objetivos, todos os povos podem dispor livremente de suas riquezas e de seus recursos naturais, sem prejuízo das obrigações decorrentes da cooperação econômica 
internacional, baseada no princípio do proveito mútuo, e do Direito Internacional. Em caso algum, poderá um povo ser privado de seus meios de subsistência. Os Estados partes do presente pacto, inclusive aqueles que tenham a responsabilidade de administrar territórios não autônomos e territórios sob tutela, deverão promover o exercício do direito à autodeterminação e respeitar esse direito, em conformidade com as disposições da Carta das Nações Unidas (grifo nosso).

6 Sobre o conceito de direitos humanos absolutos Alexy afirma: "Los derechos humanos absolutos son derechos que tienen todos frente a todos los seres humanos, grupos y Estados. El derecho a la vida es un ejemplo. Los derechos humanos relativos son derechos que tienen todos frente a, por lo menos, un ser humano, un grupo o un Estado". ALEXY, Robert, La institucionalización de los derechos humanos en el Estado Constitucional Democrático. Revista Del Instituto Bartolomé De Las Casas, v. 8, p. 21-42, Jan./Jun, 2000, p. 26.

7 No original: “Much of it was built up in the colonial era, when today's affluent countries ruled today's poor regions of the world: trading their people like cattle, destroying their political institutions and cultures, taking their lands and natural resources, and forcing products and customs upon them" (Pogge s.d. a).

8 No original: "We are preserving our great economic advantages by imposing a global economic order that is unjust [...]There is a shared institutional order that is shaped by the better-off and imposed on the worse-off" (Pogge, s.d. a).

9 No original: "Thanks to the inattention of our economists, many believe that the existing global institutional order plays no role in the persistence of severe poverty, but rather that national differences are the key factors (...) Once we break free from explanatory nationalism, global factors relevant to the persistence of severe poverty are easy to find" (Pogge, s.d. a).

10 No original: "National economies are inescapably linked financially through the balance of payments [...]. One country's surplus is another country's deficit. The risk of an unsustainable disequilibrium thus represents a persistent threat to policy independence" (Cohen, 2009. p. 20). Cohen pretendia investigar até que ponto a internacionalização de uma moeda nacional pode contribuir para postergar o ônus do ajuste no balanço de pagamentos. Com efeito, os ajustes no balanço de pagamentos costumam representar grandes custos políticos e econômicos, como corte de gastos e inflação, conforme o país esteja deficitário ou superavitário. Segundo esse autor a internacionalização de uma moeda nacional atribui flexibilidade macroeconômica ao país emissor dessa moeda, pois passa a existir uma facilidade na obtenção de financiamentos por parte do Estado emissor, tendo em vista a demanda que surge por títulos denominados na sua moeda. Isso daria ao Estado emissor um poder de influenciar a política dos outros países de forma direta ou indireta. Um exemplo clássico de influência indireta se deu durante a guerra fria, quando os soviéticos passaram a temer que os Estados Unidos confiscassem suas aplicações em dólar. Temerosos, eles começaram a depositar seus dólares na Inglaterra, dando origem ao que hoje se conhece pelo mercado como eurodólar: o mercado de dólares depositados fora dos Estados Unidos. Um exemplo de influência direta seria se os Estados Unidos tivessem realmente confiscado o dinheiro dos soviéticos. O que se critica na abordagem de Cohen é que, embora ele tenha destacado corretamente os aspectos públicos e privados do monetário ao relacionar sua análise com a funções desempenhadas pela moeda, o autor não relacionou os benefícios econômicos com os políticos, quando se sabe que a política é sobremaneira influenciada por questões econômicas.

11 Nesse sistema, os bancos emprestam grande parte dos depósitos a vista, retendo compulsoriamente apenas uma fração desses depósitos. Isso quer dizer, em termos práticos, que se todos os depositantes forem ao banco ao mesmo tempo sacar seu dinheiro o banco quebra.

12 Um ganho de senhoriagem deriva do fato de que o custo de emissão de moeda é inferior ao valor dos bens que se pode adquirir com ela.

13 A Grã-Bretanha possuía grande flexibilidade macroeconômica, podendo influenciar direta ou indiretamente a política dos outros países.

14 É possível que, após a constituição de uma rede, as relações de interdependência assimétrica fiquem tão arraigadas no corpo social a ponto de, mesmo após o abandono das regras de conexão por um dos nós, fazer com que os outros continuem a se conectar da mesma forma em relação a ele, pois o poder que outrora era sustentado por normas jurídicas transformou-se num poder econômico autossuficiente, já que os nós absorveram aquelas relações como naturais ao sistema, embora isso não seja verdade. 


\section{REFERÊNCIAS BIBLIOGRÁFICAS}

ALEXY, Robert. La institucionalización de los derechos humanos en el Estado Constitucional Democrático. Derechos y Libertades. Revista del Instituto Bartolomé de Las Casas, v. 8, p. 21-42, jan. 2000.

ALVARES, Jefferson Siqueira de Brito Alvarez. O Fim do Privilégio Exorbitante. Revista da ProcuradoriaGeral do Banco Central, v. 3, n. 2, p. 49-63, dez. 2009.

BEITZ, Charles. Liberalismo Internacional e Justiça Distributiva. Disponível em: www.scielo.br/pdf/ln/n47 /a03n47.pdf. Acesso em: 15 mar. 2011.

CAPELLA, Juán Ramon. Fruta Prohibida. Madrid: Editorial Trotta, 1997.

CARCHEDI, Gluglielmo. Frontiers of Political Economy. London: Verso, 1991.

CARVALHO, Fernando Cadim de. Bretton Woods aos 60 anos. (s. d.). Disponível em: www.ie.ufrj.br/ moeda/pdfs/bretton_woods_aos_60_anos.pdf. Acesso em: 2 fev. 2011.

COHEN, Benjamin. Currency and State Power. Revista da Procuradoria-Geral do Banco Central, v. 3, n. 2, p. 15-49, dez. 2009.

DECLARAÇÃO sobre o direito ao desenvolvimento. (1986). Disponível em: www.dhnet.org.br/direitos/ sip/onu/spovos/lex170a.htm. Acesso em: 5 ago. 2009.

DECLARAÇÃO de Princípios sobre a Tolerância. (1995). Disponível em: www.dhnet.org.br/direitos/sip/ onu/paz/dec95.htm. Acesso em: 9 out. 2010.

HABERMAS, Jürgen. A ética da discussão e a questão da verdade. São Paulo: Martins Fontes, 2004.

INTERNATIONAL MONETARY FUND. Reserve Accumulation and International Monetary Stability. (2010). Disponível em: www.imf.org/external/np/pp/eng/2010/041310.pdf. Acesso em: 8 abr. 2010.

KANT, Immanuel. Para a paz perpétua. Tradução de Bárbara Kristensen. Riancho: Instituto Galego de Estudos de Segurança Internacional e da Paz, 2006.

KEOHANE, Robert. Neorealism and its Critcs. New York: Columbia University Press, 1986.

MENGER, Carl. Principles of economics. New York: University Press, 1981.

PACTO internacional sobre direitos econômicos sociais e culturais. (1992). Disponível em:

http://portal.mj.gov.br/sedh/ct/legis_intern/pacto_dir_economicos.htm. Acesso em: 9 set. 2010.

PARADA FILHO, Américo Garcia. Os Estados Unidos e a conversão de sua dívida. (2009). Disponível em: www.cosif.com.br/publica.asp?arquivo=20090328complexoviralatas. Acesso em: 5 abr. 2011.

POGGE, Thomas. World Poverty and Human Rights. (s.d.[a]). Disponível em: www.law.georgetown.edu/ faculty/events/userfiles/file/LawPhilosophy/Fall\%202008/Pogge\%20World\%20Poverty\%20and\%20Hum an\%20Rights.pdf. Acesso em: 5 mai. 2010.

. Recognized and Violated by International Law: The Human Rights of the Global Poor. (s.d.[b]).

Disponível em:www2.ohchr.org/english/issues/poverty/expert/docs/Thomas_Pogge_new.pdf. Acesso em: 15 abr. 2011.

RAWLS, John. A Theory of Justice. Massachusetts: Harvard University Press, 1971.

. The Law of Peoples. Massachusetts: Harvard University Press, 1999.

ROTHBARD, Murray. As crises monetárias mundiais. (s. d.). Disponível em: www.mises.org.br/

Article. aspx?id=258. Acesso em: 20 jul. 2009.

SMITH, Adam. A Riqueza das Nações: Investigação sobre sua natureza e suas causas. São Paulo: Abril Cultural, 1983.

Fernando dos Santos Lopes

Rua Santa Mônica, 826

Capão Raso - 81110-400

Curitiba - PR - Brasil

fernandoslopes.lawlahotmail.com

Advogado

Pós-graduando EM CONTROLADORIA PELA Universidade Federal do Paraná 
REVISTA DIREITO GV SÃO PAULO 